\title{
TECHNOLOGICAL FEATURES OF EXTRUSION OF COMPOSITE MATERIALS BASED ON MIXTURES OF HIGH AND LOW DENSITY POLYETHYLENE AND MINERAL FILLERS
}

\author{
N.T.Kakhramanov, F.A.Mustafayeva, Kh.V.Allakhverdiyeva \\ Institute of Polymer Materials, NAS of Azerbaijan \\ najaf1946@rambler.ru
}

Received 01.04.2019

\begin{abstract}
The results of the study of the optimal mode of extrusion of composite materials based on mixtures of high-density and low density polyethylene with various mineral fillers and the selection of the optimal mode of this process are presented. As fillers, montmorillonite, bentonite, aluminum hydroxide, as well as their paired mixtures based on montmorillonite + aluminum hydroxide and bentonite + aluminum hydroxide were used. It was established that the loading of fillers into the composition of a polymer mixture of low density polyethylene +50 mass. $\%$ highdensity significantly affects the optimal technological mode of their processing. The loading of montmorillonite and bentonite into the composition of the polymer mixture is accompanied by the preservation of the melt flow index at a sufficiently high level. With the loading of aluminum hydroxide, there is a noticeable deterioration in the rheological characteristics of the composites.
\end{abstract}

Keywords: extrusion, aluminum hydroxide, montmorillonite, bentonite, rheology.

doi

\section{Introduction}

As a result of the development of various branches of industries, more and more attention is being paid to working cat new types of polymeric materials able of working in harsh extreme operating conditions. In this regard, of particular interest are polyolefins, in particular high density polyethylene (HDPE) and low density polyethylene (LDPE) [1-4]. Due to the valuable complex of properties and the ability to be processed by all known methods of plastics processing, these polyethylene have found quite a wide range of applications. Each of these polymers has certain advantages and disadvantages. For example, HDPE has high physico-mechanical properties, but at the same time a sufficiently high hardness and rigidity limits their use in the production of relatively elastic and flexible products. At the same time, LDPE is characterized by high flexibility and elasticity, however, it can not be used in the manufacture of products that require both strength and flexibility of the material. In this regard, studies aimed at obtaining such materials by compiling polymer blends based on them are becoming very interesting. By varying the ratio of HDPE:LDPE, it is possible to obtain relatively strong and flexible polymeric materials. Along with this, the loading of fillers into their composition actually makes it possible to obtain relatively new types of polymer composites with improved deformation-strength properties, in which the filler plays the role of an amplifier of polymers $[5,6]$.

The literature is very limited research aimed at studying the technological features of the processing of polymer composite materials. In connection with the above, the purpose of this work was to study the technological features of the extrusion of composite materials based on a mixture of various types of polyethylene.

\section{Experimental part}

As polymer raw materials were used HDPE and LDPE. HDPE (HD 52518 industrial high density polyethylene) has a ultimate tensile stress - 31.3 MPa, a flexural modulus - $753 \mathrm{MPa}$, an elongation at break $-435 \%$, a density of $946 \mathrm{~kg} / \mathrm{m}^{3}$, heat resistance $-119^{0} \mathrm{C}$, melting point $-131^{\circ} \mathrm{C}$, a melt flow index (MFI) of $7.8 \mathrm{~g} / 10 \mathrm{~min}$, degree of crystallinity $-78 \%$.

LDPE (industrial low density polyethylene grade 17703-01): ultimate tensile stress - 13.1 $\mathrm{MPa}$, a flexural modulus - $196 \mathrm{MPa}$, an elongation at break $-720 \%$, density $-927 \mathrm{~kg} / \mathrm{m}^{3}$, heat 
resistance $-85^{\circ} \mathrm{C}$, melting point $-106^{\circ} \mathrm{C}, \mathrm{MFI}=$ $1.7 \mathrm{~g} / 10 \mathrm{~min}$ at a temperature of $190^{\circ} \mathrm{C}$ and a load of $5 \mathrm{~kg}$, the degree of crystallinity is $60 \%$.

Montmorillonite (MM): (in other words, nanoclay) is a clay mineral belonging to the subclass of layered silicates, the main component of bentonite. The deposit of montmorillonite used by us in these studies is Dash-Salahly. The chemical composition of montmorillonite is variable: the content of $\mathrm{SiO}_{2} 45-55 \%, \mathrm{Al}_{2} \mathrm{O}_{3} 18-$ $20 \%, \mathrm{Na}_{2} \mathrm{O}$ and $\mathrm{CaO}$ up to $1.5 \%, \mathrm{H}_{2} \mathrm{O}$ up to $24-$ $26 \%$. The syngony is monoclinic, the crystalline structure is layered. The interlayer space of the nanoclay includes polar liquids (glycerin), exchange cations and anions [6]. The package is three-layered (2:1): two layers of silicon-oxygen tetrahedra converted vertices to each other, on both sides, cover a layer of aluminum hydroxyl octahedra. The presence of isomorphic substitutions, the huge specific surface area (up to 600$800 \mathrm{~m}^{2} / \mathrm{g}$ ) and the ease of penetration of ions into the interpacket space cause a significant cation exchange capacity (80-150 mmol eq/100 g). Montmorillonite is a typical weathering product of aluminosilicates. It is one of the main minerals in many soils (formed during the weathering of volcanic rocks - tuffs and ashes), it is found in many sedimentary rocks.

Bentonite is a natural clay mineral, hydroaluminosilicate, has a density of 2.66-2.84 $\mathrm{g} / \mathrm{sm}^{3}$, pH 6-9.5 (for 5\% aqueous suspension after settling for 1 hour) and contain less than $2 \%$ sodium carbonate. The deposit of bentonite used by us in these studies is Dash-Salakhly.

Aluminum hydroxide $\mathrm{Al}(\mathrm{OH})_{3}$ : a colorless solid, insoluble in water, has amphoteric properties, is part of many bauxite. Amorphous aluminum hydroxide has a variable composition $\mathrm{Al}_{2} \mathrm{O}_{3} \cdot n \mathrm{H}_{2} \mathrm{O}$. When heated above $180-200^{\circ} \mathrm{C}$ decomposes.

Melt flow index (MFI) was determined on a rheometer of the brand MELT FLOW TESTER, CEAST MF50 (INSTRON, Italy) at a temperature of $190^{\circ} \mathrm{C}$ and a load of $5 \mathrm{~kg}$.

Ultimate tensile stress and elongation at break were determined in accordance with GOST 11262-80.

Mechanico-chemical modification of polymer mixtures was carried out on a single-screw extruder with the ratio $L / D=24$, consists of 4 zones: the loading zone, the compression zone, the dosing zone, the extruder head. The number of turnovers of the screw was regulated using an asynchronous motor. The head is equipped with a slotted console, which allows to obtain continuous sheets $2 \mathrm{~mm}$ thick and $100 \mathrm{~mm}$ wide. The blades were cut from these sheets to determine the strength characteristics and the elongation at break of polymer composites. After dry mixing of the components in the ball mill: LDPE +50 mass.\% HDPE + filler was loaded into the extruder through the loading zone. The temperature of the material cylinder was selected depending on the type and ratio of the used components of the polymer mixture.

\section{Results and discussion}

In the study of issues related to the processing of polymer composite materials, it is very important to correctly focus on the technological parameters that are the determining factors in the optimization of the extrusion mode. As a rule, the determining factors of the extrusion process are the temperature conditions of the material cylinder by zones, shaft rotational speed, screw construction and geometry, drawing speed, molded product cooling temperature, etc. Another very decisive factor is the type of polymer, filler concentration, technological miscibility and melt flow rate of mineral-polymer systems. Of these factors affecting the technology of the extrusion process, the most important are the temperature condition of extrusion, the screw rotation speed, the ratio of polymer components, technological compatibility and the MFI of composite materials [7-10]. Temperature mode of extrusion essentially adjusts the melt viscosity of composite. At very high temperatures, the viscosity of the melt decreases to such an extent that it causes problems with cooling the extrudate, which, as a rule, is accompanied by a decrease in the quality of its surface and a violation of the integrity of the polymer mass in the product. At a relatively low temperature, the melt viscosity increases to such an extent that the extrusion rate and the surface quality of the product sharply decrease. An excessive increase in the speed of rotation of the screw leads to the fact that the polymer mass does not have time to warm up to the desired temperature and therefore there is 
cold extrusion, which usually ends with the appearance of cracks on the surface of the extrudate.

Table 1 presents the results of experimental studies on the choice of the optimal mode of extrusion for polymer mixtures HDPE+LDPE with different ratios of the blend components. As can be seen from this table, as the proportion of HDPE in the mixture of HDPE+LDPE increases, the optimum extrusion temperature condition shifts to relatively high temperatures region. And this circumstance is quite understandable, since LDPE has a melting point within $106^{\circ} \mathrm{C}$, while HDPE has a value of this indicator within $131{ }^{\circ} \mathrm{C}$. Comparative analysis of the data in this table shows that along with this, an increase in the extrusion pressure, the number of turnovers of the screw and the MFI of composite materials is observed. The mere fact of the existence of a certain regularity in the change of characteristic technological parameters and properties indicates a uniform mutual dispersion of the mixture components.

The next stage of the research was the study of the separate influence of various mineral fillers (montmorillonite, bentonite and aluminum hydroxide) on the selection of the optimal extrusion mode of composite materials. We believed that after identifying the role of a single mineral filler on the technological features of the extrusion process, it would be correct to consider the effect of 2 pairs of fillers: montmorillo- nite $+\mathrm{Al}(\mathrm{OH})_{3}$ and bentonite $+\mathrm{Al}(\mathrm{OH})_{3}$ on optimizing the process of processing composites based on LDPE + 50 mass.\% HDPE. The choice of these pairs of fillers in the composition of polymer mixtures was due primarily to the need to produce fire-resistant composite materials.

Tables 2-4 present the results of the study of the effect of various mineral fillers on the optimal technological parameters of the process of extrusion of composites using a monotrem technology. As filler used montmorillonite, bentonite and $\mathrm{Al}(\mathrm{OH})_{3}$. According to this technology, in each individual case, the components are simultaneously loading into the polymer composition (PC, with bentonite PCB) as a result of which it is possible to obtain materials with specified properties in a single process. The extrusion method is one of the most simple and effective methods of mixing and obtaining composite materials [11-13]. In this paper, we tried to show the most optimal conditions for obtaining composite materials with various fillers and their content in the polymer matrix. It should be taken into consideration and the fact that the considered fillers have different effects on the technological characteristics of the extrusion.

For example, it was possible to assume that the loading of the above-mentioned fillers will increase the melt viscosity and, as a consequence, decrease the melt flow rate of the composites.

Table 1. Optimum temperature condition of extrusion of a mixture of thermoplastic polyolefins LDPE + HDPE

\begin{tabular}{|c|c|c|c|c|}
\hline $\begin{array}{c}\text { Composition formulation, } \\
\text { mass. } \%\end{array}$ & $\begin{array}{c}\text { Extrusion temperature in } \\
\text { cylinder zones, } \\
T,{ }^{0} \mathrm{C}\end{array}$ & $\begin{array}{c}\text { Extrusion } \\
\text { pressure, } \\
\text { MPa }\end{array}$ & $\begin{array}{c}\text { The number of turno- } \\
\text { vers of the screw, } \\
\text { turnover/min }\end{array}$ & $\begin{array}{c}\text { MFI, } \\
\text { g/10min }\end{array}$ \\
\hline LDPE & $100-120-140-150^{*}$ & 4.2 & 12 & 1.7 \\
LDPE+10HDPE & $110-130-160-170^{*}$ & 4.2 & 12 & 1.7 \\
LDPE+30HDPE & $120-140-160-180^{*}$ & 5.6 & 14 & 1.9 \\
LDPE+50HDPE & $120-150-170-190^{*}$ & 6.4 & 15 & 2.2 \\
LDPE+70HDPE & $120-150-180-200^{*}$ & 6.9 & 15 & 2.7 \\
HDPE & $130-160-190-200^{*}$ & 7.0 & 1.8 & 7.8 \\
\hline
\end{tabular}

*temperature in the extruder head.

Table 2. Optimum temperature condition of extrusion of a mixture of thermoplastic polyolefins(PM) LDPE +50 mass.\% HDPE + montmorillonite (MM)

\begin{tabular}{|c|c|c|c|c|}
\hline $\begin{array}{c}\text { Composition of composite } \\
\text { LDPE+50HDPE+MM, } \\
\text { mass.\% }\end{array}$ & $\begin{array}{c}\text { Extrusion temperature in } \\
\text { cylinder zones, } \\
T,{ }^{0} \mathrm{C}\end{array}$ & $\begin{array}{c}\text { Extrusion } \\
\text { pressure, } \\
\text { MPa }\end{array}$ & $\begin{array}{c}\text { The number of turno- } \\
\text { vers of the screw, } \\
\text { turnover/min }\end{array}$ & $\begin{array}{c}\text { MFI, } \\
\mathrm{g} / 10 \mathrm{~min}\end{array}$ \\
\hline PM+5MM & $120-150-170-190^{*}$ & 6.4 & 14 & 2.9 \\
PM+10MM & $120-150-170-190^{*}$ & 6.2 & 14 & 3.6 \\
PM+20MM & $120-150-180-190^{*}$ & 6.5 & 15 & 3.8 \\
PM+30MM & $120-160-180-200^{*}$ & 6.9 & 15 & 2.8 \\
\hline
\end{tabular}

LDPE+50HDPE (PM), * temperature in the extruder head, montmorillonite (MM). 
Table 3. Optimum temperature mode of extrusion of a mixture of thermoplastic polyolefins LDPE + 50wt. $\% \mathrm{HDPE}+$ bentonite (B)

\begin{tabular}{|c|c|c|c|c|}
\hline $\begin{array}{c}\text { Composition of compo- } \\
\text { site LDPE+50HDPE+B, } \\
\text { wt.\% }\end{array}$ & $\begin{array}{c}\text { Extrusion temperature in } \\
\text { cylinder zones, } \\
T, \mathrm{C}\end{array}$ & $\begin{array}{c}\text { Extrusion pres- } \\
\text { sure, } \\
\mathrm{MPa}\end{array}$ & $\begin{array}{c}\text { The number of } \\
\text { turnovers of the } \\
\text { screw, } \\
\text { turnover/min }\end{array}$ & $\begin{array}{c}\text { MFI, } \\
\mathrm{g} / 10 \mathrm{~min}\end{array}$ \\
\hline PM+ 5 B & $120-150-170-190^{*}$ & 7.1 & 14 & 2.7 \\
PM +10B & $120-150-170-190^{*}$ & 7.1 & 15 & 2.5 \\
PM +20B & $120-150-180-190^{*}$ & 7.4 & 15 & 2.1 \\
PM +30B & $120-160-180-200^{*}$ & 7.8 & 16 & 1.9 \\
\hline
\end{tabular}

LDPE+50HDPE (PM), * temperature in the extruder head, bentonite (B).

Table-4. Optimum temperature condition of extrusion of a mixture of thermoplastic polyolefins LDPE $+50 \mathrm{mass} . \%$ $\mathrm{HDPE}+\mathrm{Al}(\mathrm{OH})_{3}(\mathrm{~A})$

\begin{tabular}{|c|c|c|c|c|}
\hline $\begin{array}{c}\text { Composition of composite } \\
\text { LDPE+50HDPE+A, } \\
\text { mass.\% }\end{array}$ & $\begin{array}{c}\text { Extrusion temperature in } \\
\text { cylinder zones, } \\
T,{ }^{0} \mathrm{C}\end{array}$ & $\begin{array}{c}\text { Extrusion pres- } \\
\text { sure, } \\
\mathrm{MPa}\end{array}$ & $\begin{array}{c}\text { The number of } \\
\text { turnovers of the } \\
\text { screw, } \\
\text { turnover/min }\end{array}$ & $\begin{array}{c}\text { MFI, } \\
\mathrm{g} / 10 \mathrm{~min}\end{array}$ \\
\hline PM+5A & $120-150-170-190^{*}$ & 7.1 & 13 & 2.0 \\
PM +10A & $120-150-180-190^{*}$ & 7.7 & 13 & 1.3 \\
PM +30A & $130-170-180-200^{*}$ & 8.6 & 14 & 0.6 \\
\hline
\end{tabular}

$\mathrm{LDPE}+50 \mathrm{HDPE}(\mathrm{PM}), *$ temperature in the extruder head, $\mathrm{Al}(\mathrm{OH})_{3}(\mathrm{~A})$.

Preliminary studies of composites have shown that the loading of montmorillonite and bentonite not only does not contribute to an increase in the melt viscosity, but, on the contrary, leads to their decrease. According to the data of Table 2 with an increase in the concentration of montmorillonite to 20 mass.\% the content is set to some increase in the MFI of the composites. Only when the concentration of the filler is more than $20 \mathrm{wt} . \%$ there is a slight decrease in the MFI of the composites.

Table 3 presents the optimal technological conditions for the extrusion of composite materials based on polymer mixtures and bentonite. From a comparative analysis of the data provided in Tables 2 and 3, it is possible to establish that the temperature condition of extrusion of composites containing montmorillonite and bentonite practically does not differ. The difference is found in the change at extrusion pressure, according to which the composites containing bentonite have an extrusion pressure slightly higher.

Tangible changes were found in an experimental study of the process of extrusion of composites containing $\mathrm{Al}(\mathrm{OH})_{3}$, the results of which are summarized in Table 4. According to the data obtained, the temperature mode of extrusion of composites containing $\mathrm{Al}(\mathrm{OH})_{3}$ is higher than that of previous composites. In ad dition, a regular decrease in the MFI of the composites under consideration was found. This decrease is primarily interpreted by an increase in the melt viscosity of the composites, due to the poor compatibility of the polymer matrix with aluminum hydroxide. The absence of compatibility of the considered composites was evidenced by the results of the analysis of physico-mechanical properties, according to which with an increase in the $\mathrm{Al}(\mathrm{OH})_{3}$ concentration from 5.0 to 30 mass.\% ultimate tensile stress decreased from 18.8 to $12.4 \mathrm{MPa}$. At the same time, the loading of the same content of bentonite led to a decrease in ultimate tensile stress from 19.3 to $18.2 \mathrm{MPa}$. From the data obtained, it follows that, in contrast to aluminum hydroxide, bentonite contributes to a much lesser extent to a decrease in the value of this indicator. All these detected regularities once again prove the high selectivity of the influence of the type of filler on the compatibility and deformationstrength characteristics of composite materials.

Tables 5 and 6 summarize the results of the studying fillers, effect of different pairs on technological mode of processing the composite materials. The need for simultaneous loading of several fillers into the polymer matrix was associated with the possibility of using the useful features of the structure of each of them in the composite. 
Table 5. Optimum temperature mode of extrusion of a mixture of thermoplastic polyolefins LDPE+50 mass. $\%$ HDPE + 20 mass.\% bentonite $+\mathrm{Al}(\mathrm{OH})_{3}$

\begin{tabular}{|c|c|c|c|c|}
\hline $\begin{array}{c}\text { Composition of composite } \\
\text { mass.\% }\end{array}$ & $\begin{array}{c}\text { Extrusion temperature in } \\
\text { cylinder zones, } \\
\mathrm{T}^{0} \mathrm{C}\end{array}$ & $\begin{array}{c}\text { Extrusion } \\
\text { pressure, } \\
\mathrm{MPa}\end{array}$ & $\begin{array}{c}\text { The number of } \\
\text { turnovers of the } \\
\text { screw, } \\
\text { turnover/min }\end{array}$ & $\begin{array}{c}\text { MFI, } \\
\mathrm{g} / 10 \mathrm{~min}\end{array}$ \\
\hline PCB+5A & $130-150-170-190^{*}$ & 7.1 & 14 & 1.8 \\
PCB +10A & $130-160-180-190^{*}$ & 7.9 & 14 & 1.6 \\
PCB +20A & $130-160-190-200^{*}$ & 8.3 & 15 & 1.2 \\
\hline
\end{tabular}

$\mathrm{Al}(\mathrm{OH})_{3}-(\mathrm{A}), *$ temperature in the extruder head, LDPE+50 mass.\% HDPE+20 mass.\% bentonite (PCB)

Table 6. Optimum temperature condition of extrusion of a mixture of thermoplastic polyolefins LDPE+50 wt.\% HDPE +20 wt. $\%$ montmorillonite $+\mathrm{Al}(\mathrm{OH})_{3}$

\begin{tabular}{|c|c|c|c|c|}
\hline $\begin{array}{c}\text { Composition of composite } \\
\text { LDPE+50HDPE+20MM+A, } \\
\text { wt.\% }\end{array}$ & $\begin{array}{c}\text { Extrusion temperature in } \\
\text { cylinder zones, } \\
T,{ }^{0} \mathrm{C}\end{array}$ & $\begin{array}{c}\text { Extrusion pres- } \\
\text { sure, } \\
\text { MPa }\end{array}$ & $\begin{array}{c}\text { The number of turno- } \\
\text { vers of the screw, } \\
\text { turnover / min }\end{array}$ & $\begin{array}{c}\text { MFI, } \\
\mathrm{g} / 10 \mathrm{~min}\end{array}$ \\
\hline PCM+ 5A & $130-150-170-190^{*}$ & 7.3 & 14 & 3.4 \\
PCM+10A & $130-160-180-190^{*}$ & 7.8 & 14 & 2.9 \\
PCM+20A & $130-160-190-210^{*}$ & 8.4 & 14 & 1.5 \\
PCM+30A & $140-170-200-210^{*}$ & 9.3 & 15 & 0.3 \\
\hline
\end{tabular}

$\mathrm{Al}(\mathrm{OH})_{3}-(\mathrm{A})$, * temperature in the extruder head, LDPE + 50mass.\% HDPE+ 20 mass.\% montmorillonite (PCM).

The concentration of the mineral fillers of montmorillonite and bentonite in the composition of the composite was $20 \mathrm{wt} . \%$, at which relatively satisfactory properties were achieved. Taking into account that bentonite and montmorillonite, when loading into the polymer mixture, the MFI composites practically remain at a level sufficient for their processing by extrusion as the second filler we used aluminum hydroxide.

As can be seen from Tables 5 and 6, with an increase in the concentration of $\mathrm{Al}(\mathrm{OH})_{3}$ in a mixture with bentonite and montmorillonite, the MFI of the samples decreases slightly, but at the same time remains at a level sufficient for their processing by extrusion. Analyzing the data presented in this table, it can be noted that as the content of aluminum hydroxide increases, an increase in the temperature made of the material cylinder is observed. This fact clearly indicates that the loading of aluminum hydroxide is accompanied by a sharp increase in the effective melt viscosity of the composite. Therefore, in order to improve its processability, measures are being taken to increase the temperature condition of extrusion. It should also take into account the fact that to the original composite with 20 mass. $\%$ the content of the layered mineral filler is added from 5.0 to 30 mass. \% aluminum hydroxide. Thus, the developed materials in total will contribute to the production of materials containing from 25 to 50 mass.\% filler. Therefore, the studied multicomponent composites should be considered as highly filled polymer systems.

Based on the foregoing, it can be concluded that the loading of various types of mineral fillers into the composition of polymer mixtures of LDPE + 50 mass.\% HDPE has a selective effect on the technological features of their processing. Those fillers that have a layered structure (bentonite and montmorillonite) have a positive effect on the increase in the MFI of composites and on the technological features of their processing.

The loading of aluminum hydroxide affects the decrease in the MFI of the samples that makes difficult their processing by extrusion, especially at high concentrations in the polymer mixture.

The simultaneous use of a layered filler with aluminum hydroxide allows you to maintain a satisfactory level of MFI composites.

\section{References}

1. Nguen Min Tuan, Chalaya N.M., Osipchik V.S. Struktura i fiziko-mekhanicheskie svojstva smesej polipropilena i metallocenovogo ehtilenpropilenovogo ehlastomera. Plast. massy. 2017. № 9-10. S.12-16.

2. Simonov-Emelyanov I.D. Principy sozdaniya i pererabotki kompozicionnyh materialov dispersnoj struktury. Plast. massy. 2005. № 1. S.11-16. 
3. Kravchenko T.P., Ermakov S.N., Kerber M.L. i dr. Nauchno-tekhnicheskie problemy polucheniya kompozicionnyh materialov na osnove konstrukcionnyh termoplastov Plast. massy. 2010. № 10. S. 32-37.

4. Yong K. Kim. 5-The use of polyolefins in industrial and medical applications. Pages 135-155. Polyolefin Fibres (Second Edition). Structure, Properties and Industrial Applications. The Textile Institute Book Series. Woodhead Publishing, 2017. 590 p.

5. Kahramanly Yu.N. Nesovmestimye polimernye smesi i kompozicionnye materialy na ih osnove. Elm, 2013. $152 \mathrm{~s}$.

6. Kahramanov N.T., Arzumanova N.B., Peseckij S.S., Ismailzade A.D. Reologicheskie svojstva nanokompozitov na osnove klinoptillolita i bloksopolimera propilena s ehtilenom / Kompozity i nanostruktury. 2018. T.10. №1(37). S.21-27.

7. Kazakov YU.M., Volkov A.M., Ryzhikova I.G., Bauman N.A., Volfson S.I. Binarnye smesi etilen$\alpha$-olefinovyh ehlastomerov dlya uluchsheniya balansa udaro- i deformacionno-prochnostnyh harakteristik kompozicij polipropilena, poluchaemyh $\mathrm{v}$ processe reakcionnoj ehkstruzii. Plast. massy. 2016. № 9-10. S. 3-6.
8. Mozzhuhin V.B., Milov V.I., Bespalova O.V., Boldyreva S.D. Vliyanie tekhnologicheskogo oborudovaniya i tekhnologii polucheniya vysokonapolnennyh kompozicij na osnove poliolefinov na ih fiziko-mekhanicheskie svojstva. Plast. massy. 2013. № 1. S. 54-56.

9. Pomogajlo A.D. Molekulyarnye polimerpolimernye kompozicii. Sinteticheskie aspekty Uspekhi himii. 2002. T. 71. № 1. S. 5-38.

10. Eldridge M.MountIII. 12-Extrusion Processes. Pages 217-264. Applied Plastics Engineering Handbook (Second Edition). Processing, Materials, and Applications. Plastics Design Library. Imprint: William Andrew, 2017. 784 p.

11. Gusejnova Z.N. Modificirovanie kompozicij PEH+PP razlichnymi kauchukami v prisutstvii tellura Plast. massy. 2011. № 4. S. 43-45.

12. Yakovlev Y.U., Hasyanov R.SH., Galiguzov A.A., Malaho A.P. Osobennosti tekuchesti rasplava RERT - poliehtilena napolnennogo bazaltovym i steklyannymi voloknami Plast. massy. 2018. № 910. S. 49-52.

13. Dudochkina E.A., Lyamkin D.I., Rudakov G.F. Modifikaciya tekhnologicheskih i mekhanicheskih svojstv vysokonapolnennyh poliehtilenovyh kompozicij. Plast. massy. 2018. № 7-8. S. 44-47.

\section{AŞAĞI Və YUXARI SIXLIQLI POLIETILEN QARIŞIĞI Və MINERAL DOLDURUCULAR ĐSASINDA OLAN KOMPOZIT MATERİALLARIN EKSTRUZIYYSININ TEXNOLOJI XÜSUSIYYOTLORİ}

\section{N.T.Qəhrəmanov, F.尹.Mustafayeva, X.V.Allahverdiyeva}

Aşağı sıxlıqlı polietilen və yuxarı sıxlıqlı polietilen qarışı̆̆ı və müxtəlif mineral doldurucular əsasında olan kompozit materilların ekstruziyasının optimal rejiminin tədqiqat nəticələri verilmişdir. Doldurcu olaraq montmorillonit, bentonit, alüminium hidroksid, və həmçinin onların montmorillonit+alüminium hidroksid və bentonit+alüminium hidroksid əsaslı cütt qarışıqları istifadə olunmuşdur. Müəyyən olunmuşdur ki, Aşağı sıxlıqlı polietilen +50 kütlə\% yuxarı sıxlıqlı polietilen polimer qarışı̆̆ının tərkibinə doldurucuların daxil edilməsi onların emalının optimal texnoloji rejiminə əhəmiyyətli təsir göstərir. Montmorillonit və bentonitin polimer qarışığın tərkibinə daxil edilməsi ərintinin axıcılıq göstəricinin kifayət qədər yüksək səviyyədə saxlanılması ilə müşayiət olunur. Alüminium hidroksidin daxil edilməsində kompozitlərin reoloji xüsusiyyətlərinin nəzərə̧̧arpacaq dərəcədə pisləşməsi müşahidə olunur.

Açar sözlor: ekstruziya, alüminium hidroksid, montmorillonit, bentonit, reologiya.

\section{ТЕХНОЛОГИЧЕСКИЕ ОСОБЕННОСТИ ЭКСТРУЗИИ КОМПОЗИТНЫХ МАТЕРИАЛОВ НА ОСНОВЕ СМЕСЕЙ ПОЛИЭТИЛЕНА ВЫСОКОЙ И НИЗКОЙ ПЛОТНОСТИ И МИНЕРАЛЬНЫХ НАПОЛНИТЕЛЕЙ}

\section{Н.Т.Кахраманов, Ф.А.Мустафаева, Х.В.Аллахвердиева}

Приводятся результаты исследования экструзии композитных материалов на основе смесей полиэтиленов высокой (ПЭВП) и низкой плотности (ПЭНП) с различными минеральными наполнителями и выбор оптимального режима процесса. В качестве наполнителей использовали монтмориллонит, бентонит, гидроксид алюминия, а также их парные смеси на базе мотмориллонит+гидроксид алюминия и бентонит+гидроксид алюминия. Установлено, что введение наполнителей в состав полимерной смеси ПЭНП+50 масс.\% ПЭВП существенным образом влияет на оптимальный технологический режим их переработки. Введение монтмориллонита и бентонита в состав полимерной смеси сопровождается сохранением показателя текучести расплава на достаточно высоком уровне. При введении гидроксида алюминия наблюдается заметное ухудшение реологических характеристик композитов.

Ключевые слова: экструзия, гидроксид алюминия, монтмориллонит, бентонит, реология. 